\title{
OLAHRAGA BAGI PENDERITA HIPERTENSI
}

Oleh: Yudik Prasetyo

Dosen Jurusan Pendidikan Kesehatan dan Rekreasi FIK UNY

Abstrak

Klasifikasi tckanan darah tinggi menurut WH(), adalah tckanan darah normal, jika sistolik kurang atau sama dengan 14.) $\mathrm{mmHg}$ dan diastolik kurang atau sama dengan $90 \mathrm{mmHg}$. Tekanan darah perbatasan, di mana sistolik 14.1-14.9 mmHg dan diastolik 91-94 mmHg. Tekanan darah tinggi, jika sistolik lcbih besar atau sama dengan $160 \mathrm{mmHg}$ dan diastolik lebih besar atau sama dengan $9.5 \mathrm{mmHg}$. Mekanisme terjadinya hipertensi adalah melalui terbentuknya angiotensin II dari angiotensin I oleh angiotensin I-converting enzyme (ACE). ACE memegang peran lisiologis penting dalam mengatur tckanan darah.

Olahraga cndurance, dapat menurunkan tckanan sistolik maupun diastolik pada orang yang mempunyai tckanan darah tinggi tingkat ringan. Olahraga acrobik menimbulkan clck seperti: beta blocker yang dapat menenangkan sistem saral simpatikus dan melambatkan denyut jantung. Jenis olahraga yang efcktif menurunkan tckanan darah adalah olahraga acrobik dengan intensitas sedang (70-80\%). Salah satu contohnya, jalan kaki cepat. Frekuensi latihannya 3 - 5 kali seminggu, dengan lama latihan 20 - 60 menit sckali latihan. Latihan olahraga bisa menurunkan tekanan darah karena latihan itu dapat merilekskan pembuluh-pembuluh darah.

Kata kunci: olahraga, hipertensi 
Istilah hipertensi berasal dari bahasa Inggris "hypertension". Kata "hypertension" sendiri berasal dari bahasa Latin, yaitu "hyper" dan "tension". "hyper" berarti tekanan atau tegangan. Akhirnya hypertension menjadi istilah kedokteran yang cukup populer untuk menyebut penyakit tekanan darah tinggi. Selain itu, dalam bahasa Inggris digunakan juga istilah "high blood pressure" yang berarti tekanan darah tinggi (http://www.pikiranrakyat.com).

Manusia selama 24 jam tidak tinggal diam, mungkin tidur 6-8 jam, duduk 3 jam, berjalan 1 jam, bekerja 8 jam, olahraga 15 menil dan sebagainya. Tekanan darah umumnya diukur saat istirahat dalam posisi berbaring atau duduk. Tekanan darah diukur memakai alat Manometer Air Raksa atau alat elektronik pada lengan kanan. Saat ini sudah tcrdapat alat pengukur tekanan darah sclama 24 jam (21 hour ambulatory blood pressurc) yang dapat digunakan untuk mengetahui lluktuasi tckanan darah scsecrang secara tepat, sehingga diagnosa hipertensi maupun elek pengobatan dapat diketahui secara akurat. Tekanan darah tidak hanya dipengaruhi olch aktivitas fisik tetapi juga oleh emosi, sehingga bisa saja sescorang dianggap menderita hipertensi saat diperiksa olch dokter namun scbenarnya kenaikan tckanan darah saat diperiksa mungkin karena laktor cmosi (Dede Kusmana, 2(0)6): 89).

Tinggi-rendahnya tckanan darah ditcntukan olch tckanan darah sistolik (tekanan darah paling tinggi ketika jantung berkerut memompa darah ke dalam arteri) dan tckanan darah diastolik (tckanan darah ketika jantung istirahat sekejap di antara dua denyutan). Keduanya diukur bersama dan

MEDIKORA Vol.III, No 1, April 2007:1-17 
hasilnya dituliskan dengan pola angka tckanan darah sistolik/diastolik. Contohnya, 120/80 mmHg. Denyut jantung scndiri berlangsung antara 60)80 denyut per menit. (http://radmarssy.wordpress.com).
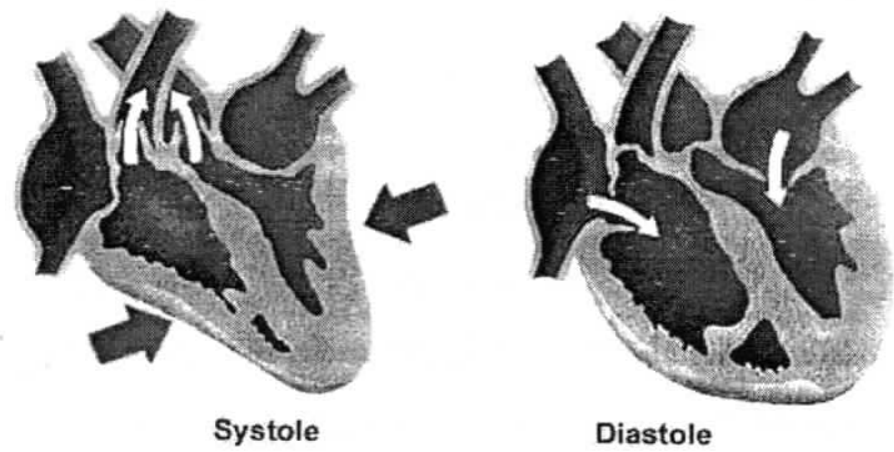

Gambar 1. Sistolik dan diastolik (http://imagcs.googlc.co.id/url?q)

Klasifikasi tekanan darah tinggi menurut World Hcalth Organization (WHO), organisasi kesehatan dunia di bawah Perserikatan Bangsa-Bangsa (PBB) adalah sebagai berikut: tekanan darah normal, jika sistolik kurang atau sama dengan $140 \mathrm{mmHg}$ dan diaslolik kurang atau sama dengan $90 \mathrm{mmHg}$. Tekanan darah perbalasan, di mana sistolik 1.1-1.199 mmHg dan diastolik 91-94 mmHg. Tekanan darah tinggi alau hipertensi, yaitu jika sistolik lebih besar atau sama dengan $160 \mathrm{mmHg}$ dan diastolik lcbih besar atau sama dengan $95 \mathrm{mmHg}$ (http://www.pikiran-rakyat.com).

Olahraga Bagi Penderita Hipertensi (Yudik Presetyo) 
Tabel 1. Klasifikasi tekanan darah tinggi

\begin{tabular}{|c|l|l|}
\hline No & Klasifikasi tekanan darah tinggi & \multicolumn{1}{|c|}{ Sistolik/ diastolik } \\
\hline 1. & Tekanan darah normal & $\leq 14() \mathrm{mmHg} / \leq 90 \mathrm{mmHg}$ \\
\hline 2. & Tekanan darah perbatasan & $141-149 \mathrm{mmHg} / 91-94 \mathrm{mmHg}$ \\
\hline 3. & Tekanan darah tinggi & $\geq 16() \mathrm{mmHg} / \geq 95 \mathrm{mmHg}$ \\
\hline
\end{tabular}

\section{HAL-HAL YANG PERLU DIPERHATIKAN}

Hasil Survei Keschatan Rumah Tangga menunjukkan prevalensi penyakit hipertensi atau tckanan darah tinggi di Indoncsia cukup) tinggi, yaitu 83 per 1.000) anggota rumah tangga. Pada umumnya percmpuan lebih banyak menderita hipertensi dibandingkan dengan pria. Prevalensinya di dacrah luar Jawa dan Bali lebih besar dibandingkan di kedua pulau itu. Hal tersebut terkail erat dengan pola makan, terutama konsumsi garam, yang umumnya lebih tinggi di luar Pulau Jawa dan Bali. Pengaturan menu bagi penderita hipertensi dapat dilakukan dengan empat cara. Cara pertama adalah dict rendah garam, yang terdiri dari dict ringan (konsumsi garam 3,7.5-7,5 gram per hari), menengah (1,25-3,7.5 gram per hari) dan berat (kurang dari 1,2.5 gram per hari). Cara kedua, diet rendah kolesterol dan lemak terbatas. Cara ketiga, dict tinggi serat dan kecmpat, dict rendah encrgi (bagi yang kegemukan). (Made Astawan, www.depkes.go.id/).

MEDIKORA Vol.III, No 1, April 20(07:1-17 
Untuk mencapai tekanan darah normal, sclain mclakukan olahraga secara rutin dengan takaran cukup, bebcrapa hal di bawah ini juga perlu mendapat perhatian:

1. Jika kclebihan berat badan.

Seseorang yang mengalami kelebihan bobot badan, kemungkinan mengalami hipertensi meningkat lebih dari tiga kali lipat. Resiko itu akan terus meningkat dengan bertambahnya bobot badan. Menurunkan berat badan merupakan strategi sangat cfektil dalam mengatur pola hidup untuk menormalkan tckanan darah. Bila kita berhasil menurunkan bolot badan 2,5 - $5 \mathrm{~kg}$ saja, tekanan darah diastolik dapat diturunkan scbanyak $5 \mathrm{mmHg}$. Penurunan bobot badan $10 \mathrm{~kg}$ dapat melipatduakan perbaikan ini.

2. Kurangi asupan natrium (sodium).

Apabila seseorang mendapal asupan garam secara berlebihan dalam jangka waktu lama kemungkinan mengalami tekanan darah tinggi lebih besar. Karena itu, kurangi asupan garam sampai kurang dari 2.30) $\mathrm{mg}$ (satu sendok teh) setiap hari. Dalam banyak penclitian dikctahui, pengurangan konsumsi garam menjadi setengah sendok teh per hari, dapat menurunkan tckanan sistolik scbanyak $5 \mathrm{mmHg}$ dan tckanan darah diastolik sckitar 2,5 mmHg. Pengaruh ini kcbanyakan terjadi pada para lanjut usia.

3. Usahakan cukup asupan kalium (potassium).

Mineral ini menurunkan tekanan darah dengan meningkatkan jumlah natrium yang terbuang bersama air kencing. Kalium banyak terdapat 
dalam buah-buahan dan sayur-mayur. Dengan setidaknya mengonsumsi buah-buahan sebanyak $3-5$ kali dalam schari, sescorang bisa mencapai asupan potasium yang cukup.

4. Batasi konsumsi alkohol.

Konsumsi alkohol berlebihan dapat meningkatkan tckanan darah. Para peminum berat mempunyai resiko mengalami hipertensi empat kali lebih besar ketimbang mereka yang tidak minum-minuman beralkohol. Jelaslah, kalau mereka menghilangkan kcbiasaan terscbut, tckanan darahnya akan turun.

(htp://radmarssy.wordpress.com).

\section{MEKANISME FISIOLOGI TERJADINYA HIPERTENSI}

Mekanisme terjadinya hipertensi scbenarnya terlihat dengan timbulnya gejala-gejala hipertensi antara lain pusing, muka merah, sakit kepala, keluar darah dari hidung secara tiba-tiba, tengkuk terasa pegal, dan lain-lain. Dampak yang dapat ditimbulkan olch hipertensi adalah kerusakan ginjal, pendarahan pada sclaput bening (retina mata), pecahnya pembuluh darah di otak, serta kclumpuhan.

Hipertensi discbabkan peningkatan tonus otot polos raskular perifer yang menyebabkan peningkatan resistensi arteriola dan menurunnya kapasitas sistem pembuluh vena. Hipertensi tanpa gejala, hipertensi kroniksistolik/diastolik dapat menycbabkan gagal jantung kongcstil, inlark jantung, kerusakan ginjal dan cedera scrcbrovaskular. Jika hipertensi terdiagnosis lebih awal dan diobati dengan baik maka insiden morbiditas (angka kesakitan) dan

MEDIKORA Vol.III, No 1, April 2007:1-17 
mortalitas (angka kematian) segera menurun ((hup://www.pikiranrakyat.com).

Mckanisme terjadinya hipertensi adalah melalui terbentuknya angiotensin II dari angiotensin I olch angiotensin I-converting enzyme (ACl). ACE memegang peran lisiologis penting dalam mengatur tckanan darah. Darah mengandung angiotensinogen yang diproduksi di hati. Sclanjutnya oleh hormon, renin (diproduksi oleh ginjal) akan diubah menjadi angiotensin I. Oleh ACE yang terdapat di paru-paru, angiotensin I diubah menjąadi angiotensin II. Angiotensin II inilah yang memiliki peranan kunci dalam menaikkan tekanan darah melalui dua aksi utama.

Aksi pertama adalah meningkatkan sekresi hormon antidiuretik $(\mathrm{ADH})$ dan rasa haus. $\mathrm{ADH}$ diproduksi di hipotalamus (kelenjar pituitari) dan bekerja pada ginjal untuk mengatur osmolalitas dan volume urin. Dengan meningkatnya $\mathrm{ADH}$, sangat sedikit urin yang diekskresikan ke luar tubuh (antidiuresis), sehingga menjadi pekat dan tinggi osmolalitasnya. I'ntuk mengencerkannya, volume cairan ckstraseluler akan ditingkatkan dengan cara menarik cairan dari bagian intrascluler. Akibatnya, volume darah meningkal, yang pada akhirnya akan meningkatkan tckanan darah. Aksi kedua adalah menstimulasi sekresi aldosteron dari korteks adrenal. Aldosteron merupakan hormon steroid yang memiliki peranan penting pada ginjal. Untuk mengatur volume cairan ekstraseluler, aldosteron akan mengurangi ckskresi $\mathrm{NaCl}$ (garam) dengan cara mercabsorpsinya dari tubulus ginjal. Naiknya konscntrasi $\mathrm{NaCl}$ akan diencerkan kembali dengan cara meningkatkan volume cairan ckstraseluler yang pada gilirannya akan meningkatkan volume dan tckanan 
darah. Angiotensin II menyebabkan penyempitan pembuluh darah (Made Astawan, www.depkes.go.id/).

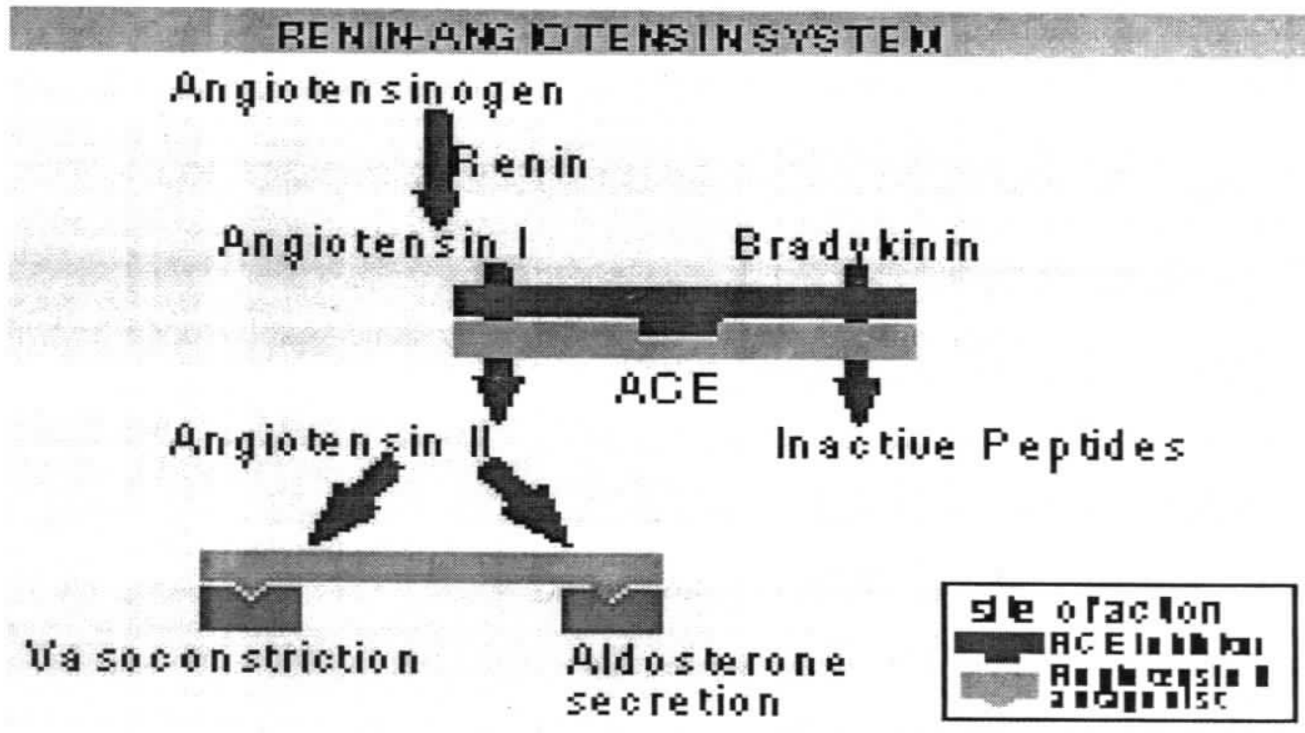

Gambar 2. Mekanisme hipertensi

Prolil hemodinamik subyek obesitas ditandai dengan peningkatan volume intravaskuler, peningkatan curah jantung dengan resistensi periler yang relatif normal. Penderita hipertensi non-obesitas perubahan hemodinamik yang terjadi adalah peningkatan resistensi periler, volume intravaskuler yang menurun dengan curah jantung yang meningkat pada awal hipertensi yang sclanjutnya kembali ke normal atau menurun pada hipertensi yang sudah berlangsung lama. Pada subyek obesitas dengan hipertensi, prolil hemodinamiknya yaitu kombinasi kedua karakteristik di atas berupa: peningkatan curah jantung, peningkatan volume intravaskuler dan peningkatan resistensi perifer (John MF Adam, 2006: 71 ).

MEDIKORA Vol.III, No 1, April 2007:1-17 


\section{OLAHRAGA BAGI PENDERITA HIPERTENSI}

Bagi penderita hipertensi laktor yang harus diperhatikan adlalah tingginya tekanan darah. Semakin tinggi tckanan darah scmakin keras kerja jantung, scbab untuk mengalirkan darah saat jantung memompa maka jantung harus mengeluarkan tenaga sesuai dengan tingginya tckanan terscbut. Jantung apabila tidak mampu memompa dengan tekanan selinggi itu, berarti jantung akan gagal memompa darah. Latihan olahraga dapat menurunkan tckanan sistolik maupun diastolik pada usia tengah baya yang schat dan juga mereka yang mempunyai tekanan darah tinggi ringan. Latihan olahraga tidak sccara signifikan menurunkan tensi pada penderita yang mengalami hipertensi berat, tetapi paling tidak olahraga membuat seseorang menjadi lebih santai.

Pada penderita hipertensi, faktor tekanan darah memegang peranan penting di dalam menentukan bolch tidaknya berolahraga, takaran dan jenis olahraga. Beberapa pedoman di bawah ini perlu dipenuhi scbelum memutuskan berolahraga, antara lain;

a. Penderita hipertensi dikontrol tanpa atau dengan obat terlebih dahulu tckanan darahnya, schingga tckanan darah sistolik tidak mclcbilii 160 $\mathrm{mmHg}$ dan tekanan diastolik tidak melcbihi $100 \mathrm{mmHg}$.

b. Sebelum berolahraga, perlu mendapatkan informasi mengenai penyebab hipertensinya. Selain itu, kondisi organ tubuh yang akan terpengaruh oleh penyakit tersebut seperti: keadaan jantung, keadaan ginjal, keadaan mata (untuk mengetahui derajat hipertensi), scrta pemeriksaan laboratorium darah maupun urin. Kondisi organ tersebut akan mempengaruhi keberhasilan olahraga yang dilakukan. 
c. Penderita hipertensi scbelum latihan, scbaiknya melakukan Uji Latih Jantung terlebih dahulu dengan beban (treadmill/crgomelcr) agar dapat dinilai reaksi tekanan darah dan perubahan aktilitas listrik jantung (EKG) serta menilai tingkat kapasitas lisik. Berdasarkan lıasil Uji Latih Jantung, dosis latihan dapat diberikan secara akurat.

d. Pada saat Uji Latih scbaiknya obat yang scelang diminum tctap) diteruskan, schingga dapat diketahui clektifitas obat tcrhadap kenaikan beban. Obat yang diberikan apakah sudah tepat artinya tekanan darah berada dalam lingkup ukuran normal atau masih menunjukkan reaksi hipertensi ketika diberikan tes pembebanan. Dokter akan berusaha mengatur kembali dosis obat apabila belum tepat.

e. Latihan yang dilakukan untuk meningkatkan daya tahan (cndurancc) dan tidak boleh menambah peningkatan tckanan (pressurc). ()lahraga yang tepat adalah jalan kaki, bersepeda, senam dan berenang atau olahraga aerobik.

1. Olahraga yang bersilat kompetisi tidak diperbolchkan. ()lahraga yang bersilat kompetisi akan memacu emosi, schingga mempercepat peningkatan tekanan darah.

g. Olahraga peningkatan kckuatan tidak diperbolchkan seperti angkat berat, karena menyebabkan peningkatan tekanan darah secara mendadak dan melonjak.

MEDIKORA Vol.III, No 1, April 2007:1-17 
h. Tekanan darah sccara tcratur dipcriksa scbelum dan scsudlah latihan. Olahraga pada penderita hipertensi tidak hanya ditentukan olch denyut jantung, tctapi juga berdasarkan reaksi tckanan darahınya.

i. Bagi penderita hipertensi ringan (tensi 160/95 mmHg tanpa obat), maka olahraga disertai pengaturan makan (mengurangi konsumsi garam) dan penurunan berat badan dapat menurunkan tckanan darah sampai tingkat normal $140 / 80 \mathrm{mmHg}$.

j. Penderita hipertensi umumnya berhubungan dengan beban cmosi (stress). Oleh karena itu disamping olahraga yang bersilat lisik, olahraga pengendalian cmosi seperti: medilasi, drikir dan beribadah sesuai agama masing-masing sangat penting dilakukan.

k. Hasil latihan jika menunjukkan penurunan tekanan darah, maka dosis obat yang dibcrikan scbaiknya dikurangi (menyesuaikan). (Dedc Kusmana, 2002: 112-115).

Bryant Stamford dalam penelitiannya mengungkapkan bahwa olahraga endurance, dapat menurunkan tekanan sistolik maupun diastolik pada orang yang mempunyai tckanan darah tinggi lingkat ringan. ()lahraga acrobik menimbulkan efek seperti: beta blocker yang dapat menenangkan sistem saral simpatikus dan melambatkan denyut jantung. ()lahıraga juga dapat menurunkan jumlah kcluaran noradrenalin dan hormon-hormon lain yang menycbabkan stres, yaitu yang menycbabkan pembululi-pembulul darah menciut dan menaikkan tckanan darahı (Sadoso S., 1995:93-94).

Latihan aerobik yang dilakukan agar dapat berpengaruh terhadap efisiensi kerja jantung, sebaiknya latihan berada pada intensitas sedang yaitu 
denyut jantung 150-170 per menit. Intensitas sedang kurang lebilı sama dengan 70-80\% dari kapasitas aerobik maksimal (Bompa, 1991 78). Jenis olahraga yang efektil menurunkan tckanan darah adalah olahraga acrobik dengan intensitas sedang. Salah satu contohnya, jalan kaki cepat. Frckucnsi latihannya 3 - 5 kali seminggu, dengan lama latihan 20) - 60 menit sckali latihan. Latihan olahraga bisa menurunkan tckanan darah karena latilan itu dapat merilekskan pembuluh-pembuluh darah. Lama-kclamaan, latihan olahraga dapat melemaskan pembuluh-pembuluh darah, sehingga tekanan darah menurun, sama halnya dengan melebarnya pipa air akan menurunkan tekanan air. Iatihan olahraga juga dapat menyebabkan aktivitas saral, reseptor hormon, dan produksi hormon-hormon tertentu menurun. Bagi penderita hipertensi latihan olahraga telap cukup aman.

Catatan khusus untuk penderita tckanan darah tinggi berat, misalnya dengan tekanan darah sistolik lcbih tinggi dari $180 \mathrm{mmHg}$ dan/atau tckanan darah diastolik lebih tinggi dari $110 \mathrm{mmHg}$, scbaiknya tetap mengyunakan obat-obatan penurun tekanan darah dari dokter scbelum memulai program penurunan tekanan darah dengan latihan olahıraga scsuai intensitas yang tclah ditentukan oleh instruktur/pelatih (http://radmarssy.wordpress.com).

Orang yang tidak pernah melakukan olahraga menurut penclitian Ralph Paffenharger, Ph.D., memiliki risiko mendapat tekanan darah tingyi $35 \%$ lebih besar. Hasil penclitian lain menyimpulkan orang yang tidak pernah berlatih olahraga risikonya bahkan menjadi 1,5 kalinya. Penclitian dr. Duncan membuktikan, latihan atau olahraga seperti jalan kaki atau joging, yang dilakukan sclama 16 minggu akan mengurangi kadar hormon norepinclin

MEDIKORA Vol.III, No 1, April 20(07:1-17 
(noradrenalin) dalam tubuh, yakni zat yang dikeluarkan sistcm saral yang dapat menaikkan tekanan darah. Berat badan yang berlebilı juga merupakan biang kcladi tckanan darah linggi karena orang yang kegemukan akan mengalami kckurangan oksigen dalam darah, hormon, enzim, serta kurang melakukan aktivitas lisik dan makan berlebihan. Terlalu banyak lemak dalam tubuh dapat menyebabkan badan memerlukan lebih banyak oksigen, karena jantung harus bekerja lebih keras. (Nanny S: hup://www.indomedia.com).

Kondisi penderita hipertensi secara medis berbeda dengan orang sehat. Untuk itu, perlu olahraga yang juga dilakukan secara khusus. Latihannya harus bertahap dan lidak bolch mcmaksakan diri. Gerakan dengan intensitas ringan dapat dilakukan perlahan scsuai kemampuan. Menurut Ninick Soclini SSt Ft, Fisioterapis Siloam Hospitals Surabaya, contoh latihan yang bisa diterapkan setiap hari adalah sebagai berikut:

Pemanasan:

1. Tekuk kepala ke samping, lalu tahan dengan tangan pada sisi yang sama dengan arah kepala. Tahan dengan hitungan 8-10), lalu bergantian dengan sisi lain.

2. Tautkan jari-jari kedua tangan dan angkat lurus ke atas kepala dengan posisi kedua kaki dibuka sclcbar bahu. Tahan dengan 8-10 hitungan. Rasakan tarikan bahu dan punggung.

Inti:

1. Lakukan gerakan seperti jalan di tempat dengan lambaian kedua tangan searah dengan sisi kaki yang diangkat. Iakukan perlahan dan hindari hentakan.

Olahraga Bagi Penderita Hipertensi (Yudik Presctyo) 
2. Buka kedua tangan dengan jemari mengepal dan kaki dibuka sclebar bahu.

Kedua kepalan tangan bertemu, dan ulangi gerakan scmampunya sambil mengatur napas.

3. Kedua kaki dibuka agak lebar lalu angkat tangan menyerong. Sisi kaki yang searah dengan tangan sedikit ditekuk. Tangan dilctakkan di pinggang dan kepala scarah dengan gerakan tangan. Tahan 8-1() kali hitungan lalu ganti dengan sisi lainnya.

4. Gerakan hampir sama dengan scbelumnya, tapi jari mengepal dan kedua tangan diangkat ke atas. Lakukan bergantian secara perlahın dan scmampunya.

5. Hampir sama dengan gerakan inti 1, tapi kaki dibuang ke samping. Kedua tangan dengan jemari mengepal ke arah yang berlawanan. Ulangi dengan sisi bergantian.

6. Kedua kaki dibuka lebih lebar dari bahu, satu lutut agak ditekuk dan tangan yang searah lutut di pinggang. Tangan sisi yang lain lurus kc arah lutut yang ditckuk. Ulangi gerakan ke arah scbaliknya dan lakukan semampunya.

Pendinginan:

1. Kedua kaki dibuka selebar bahu, lingkarkan satu tangan ke leher dan tahan dengan tangan lainnya. Hitungan 8-1() kali dan lakukan pada sisi lainnya.

MEDIKORA Vol.III, No 1, April 2007:1-17 
2. Posisi tetap, tautkan kedua tangan lalu gerakkan ke samping dengan gerakan sctengah putaran. Tahan 8-10 kali hitungan lalu arahkan tangan ke sisi lainnya dan tahan dengan hitungan sama.

Peningkatan aktivitas fisik berupa olahraga atau pelatihan jasmani secara tcratur, terbukti dapat menurunkan tckanan darah ke lingkat normal. Ini juga dapat menurunkan risiko scrangan hipertensi 50 persen lebil besar. Olahraga juga menyelamatkan scorang penderita hipertensi dari ancaman serangan jantung dan stroke. Pengaruh olahraga jangka panjang, empal hingga enam bulan, dapat menurunkan tekanan darah sebesar 7,4/5,8 $\mathrm{mmHg}$ tanpa bantuan obat hipertensi (http://www.indomedia.com/sripo/2()()7).

\section{KESIMPULAN}

Pengobatan tckanan darah tinggi memang multifaktoral yakni mulai dari mengurangi garam, mengurangi makanan bergizi linggi, menurunkan berat badan, dan olahraga. Pada penderita hipertensi, laktor tekanan darah memegang peranan penting di dalam menentukan bolch tidaknya berolahraga, takaran dan jenis olahraga. Jcnis olahraga yang clcktil menurunkan tekanan darah adalah olahraga aerobik dengan intensitas sedang (70-80\%). Frekuensi latihannya 3 - 5 kali seminggu, dengan lama latihan 20)60 menit sekali latihan. Olahraga seperti jalan kaki atau joging, yang dilakukan sclama 16 minggu akan mengurangi kadar hormon norcpinclin (noradrenalin) dalam tubuh, yakni zat yang dikcluarkan sistcm saral yang dapat menaikkan tekanan darah.

Olahraga Bagi Penderita Hipertensi (Yudik Preselyo) 


\section{DAFTAR PUSTAKA}

Bompa TO. (1994). Theory and Mcthodology of Training The Kicy to Athlctic Performancc. $2^{\text {mat }}$ Edition, Iowa: Kendall/Hunt Publishing Company.

Dede Kusmana. (20(2). Olahraga bagi Kcschalan.Jantung. Jakarta: Fakultas Kedokteran Universitas Indoncsia.

Dede Kusmana. (20()6). Olahraga Inntuk ()rang Schat dan Pcndcrila Pcnyakit Jantung. Jakarta: Balai Pencrbit Fakultas Kedokteran I Iniversitas Indonesia.

Hanafza Hakikat. (2007). Olahraga Turunkan Risiko Hipcrtcnsi. Sriwijaya Post, Senin, 28 Mei.

http://www.indomedia.com/sripo/20(07/05/28/2805H15.pdl. (online 26 ) Februari 2()()7).

John MF Adam. (20()6). Obcsitas dan Sindroma Mclabolik. Makassar: Fakultas Kedokteran Universitas Hasanuddin.

Made Astawan. Cegah Hipcrlcnsi dengan Pola Makan. www.depkes.go.id/ index.php?option=articles\&task=vicwarticlc\&artid=20\&Itcmid=3-23k(online 11.Juni 20)()7).

Nanny Sclamiharja. Hipcrtcnsi Terkendali, Strokc Tak Terjadi. htt)://www.indomedia. com/intisari/1999/september/hipertensi.htm (online 31 Juli 2()()7)

Ninick Soctini. Meningkatkan Stamina Pcndcrita

Hipcrtcnsi.htp://www.surya.co.id/wcb/ index2.php? option=com_content\&do_pdI=1\&id=5393. (onlinc 11 Juni 2007).

Sadoso Sumosardjuno. (1995). Pcngctahuan Praktis Keschatan dalaun ()lahluaga i. Jakarta: PYT Gramedia Pustaka Itama.

Indication Hypcrtcnsion. hup://www.li.ubc.ca/node/87 (online 26 lichruari 2()()7).

MEDIKORA Vol.III, No 1, April 20(07:1-17 
Jus Bagi Pcndcrita Hipcrtcnsi. hutp://www.pikiran-rakyal.com/cctak/) 1004/14/cakrawala/ lainnya4.hum (online 20 maret 20(07)

Mcrcdam Hipcrtcnsi Dcngan Acrobik. http://radmarssy.wordpress.com/2007/02/25/ meredam-hipertensi-dengan-aerobik/ (online 2 Juni 2007)

Sistem Jantung dan Pembuluh Darah. http://images.googlc.co.id//url?' (online 26) Februari 20()7). 